
\title{
3 Research Square \\ How is Rice Organ Painted: the Genetic Basis of Anthocyanin Biosynthesis in Rice
}

\section{Duo Xia}

Huazhong Agricultural University: Huazhong Agriculture University

\section{Hao Zhou}

Huazhong Agricultural University: Huazhong Agriculture University

\section{Pingbo Li}

Huazhong Agricultural University: Huazhong Agriculture University

\section{Bian Wu}

Huazhong Agricultural University: Huazhong Agriculture University

\section{Qinglu Zhang}

Huazhong Agricultural University: Huazhong Agriculture University

Yuqing He ( $\nabla$ yqhe@mail.hzau.edu.cn )

Huazhong Agricultural University https://orcid.org/0000-0002-4855-5991

\section{Original article}

Keywords: Anthocyanins, Flavonoid, Biosynthesis, Genetic basis, Oryza sativa L

Posted Date: November 5th, 2020

DOl: https://doi.org/10.21203/rs.3.rs-101298/v1

License: (c) (i) This work is licensed under a Creative Commons Attribution 4.0 International License. Read Full License 


\section{Abstract}

Anthocyanins are major subclasses of flavonoids, which have diverse biological functions and benefit human health. In Oryza sativa, organs exhibit various color due to the accumulation of anthocyanins. On the other hand, anthocyanins biosynthesis is a domestication related trait. Revealing the genetic basis of anthocyanins biosynthesis in rice is not only important for the engineering of anthocyanins, but also helpful for understanding the evolutionary story of Oryza sativa. Here we summarize the recent progresses in rice anthocyanins biosynthesis, including the anthocyanins biosynthetic pathway, the genes that participate in anthocyanins biosynthesis, the cloning of anthocyanins related genes and the domestication process of rice anthocyanins. Possible applications of rice anthocyanin biosynthesis genes in rice breeding and the remaining unknown mechanism of anthocyanins accumulation in stigma, apiculus and awn are also discussed.

\section{Background}

Phytochromes in plant organs and tissues play important roles in photosynthesis, defenses and reproduction. Anthocyanins, the major subclasses of flavonoid pigments, are the main secondary metabolites that give color to rice tissues (Reddy et al. 1995). Anthocyanin accumulation in plants has diverse functions, including resisting UV radiation, participating in hormone regulation, responding to biotic and abiotic stress, and benefits human (Ithal and Reddy 2004; Petroni et al. 2014; Ronald et al. 1994; Timothy and Edwina 1995). In rice, the accumulation of anthocyanins in stigma and apiculus helps to attract pollinators and aid in seed dispersal. Rice varieties with purple leaves can be planted as guarding rows to separate different materials. Black rice varieties have higher commercial value for the antioxidant activity of rice pericarp anthocyanins which is beneficial for human health. Furthermore, rice anthocyanins accumulation is a domestication related trait, which sheds light on the evolutionary history of rice.

Since the Gregor Mendel experiments in the 19th century, the potential of plant pigmentation in revealing basic rules of genetics and biochemistry has been recognized. Since the pigments accumulated tissues are immediately obvious to researchers, great achievements have been made in uncovering the molecular basis of anthocyanin biosynthesis in model plants such as petunia and maize (Dooner et al. 1991). Flowers and crops with diverse colors have been bred based on these achievements in the meanwhile. With the rapid development in functional genomics and comparative genomics, the anthocyanin biosynthetic pathway in rice has made some progresses. This review summarizes current advances in anthocyanin biosynthesis pathway in rice, which will throw light upon the evolutionary history of rice cultivation and assist in the molecular breeding of various anthocyanins accumulated rice varieties.

\section{Anthocyanin Biosynthetic Pathway}

Anthocyanins are water-soluble secondary metabolites, which can be classified into three categories: pelargonidin, cyanidin and delphinidin (Ciulu et al. 2018). The biosynthesis of anthocyanidins belongs to 
a branch of the flavonoids synthetic pathway, starting with malonyl-CoA and p-coumaroyl-CoA (Fig. 1) (Joseph et al. 1998; Ronald et al. 1994; Timothy and Edwina 1995; Winkel-Shirley 2001). Under the catalysis of chalcone synthase (CHS), three acetate units from malonyl-CoA combine with $p$-coumaroylCoA to yield tetra hydroxychalcone, the basic skeleton of anthocyanins. The yellow-colored tetra hydroxychalcone is turned into the colorless naringenin under the catalysis of chalcone isomerase $(\mathrm{CHI})$ and is further converted to dihydrokaempferol (DHK) by flavanone 3-hydroxylase (F3H). DHK can subsequently produce dihydroquercetin (DHQ) and dihydromyricetin (DHM) by hydroxylation of flavonoid 3'-hydroxylase $\left(\mathrm{F}^{\prime} \mathrm{H}\right)$ and flavonoid 3'5'-hydrolase $\left(\mathrm{F}^{\prime} \mathrm{S}^{\prime} \mathrm{H}\right)$ respectively. In the next, the three colorless dihydroflavonols (DHK, DHQ, DHM) are converted to anthocyanins through three steps. The first step is reduction of dihydroflavonols by dihydroflavonol reductase (DFR) to produce leucoanthocyanidins. Then leucoanthocyanidins are converted to anthocyanidin 3-0-glucoside through oxidation by leucoanthocyanidin oxidase (LDOX) and glycosylation by 3-glucosyl transferase (3GT) sequentially. Anthocyanidin 3-0-glucosides can be further glycosylated, methylated and acylated to produce decorated anthocyanins with different colors. Plants produce and accumulate various anthocyanidin 3-0glucosides. In colored rice, the most abundant anthocyanin is cyanidin 3-0-glucoside (Abdel-Aal et al. 2006; Helen 1991). It is worth mentioning that the brown color of rice seed is resulted from the accumulation of proanthocyanins, another subclass of flavonoid (Reddy et al. 1995). Proanthocyanins synthesis starts with the reduction of leucoanthocyanidin or cyanidin by the catalyzation of leucoanthocyanidin reductase (LAR) or anthocyanidin reductase (ANR) respectively and are further transported to vacuole to produce brown proanthocyanin derivatives (Koes et al. 2005).

\section{Anthocyanin Biosynthesis Genes}

The genes involved in anthocyanin biosynthesis have been well described and virtually isolated compared to other metabolites related genes in plants. The anthocyanin biosynthesis genes can be classified into two categories: structural genes and regulatory genes (Table 1). Structural genes encode functional enzymes that catalyze the anthocyanin biosynthesis reaction and regulatory genes mainly encode transcription factors (TFs) that regulate the expression of structural genes (Dooner et al. 1991). 
Table 1

Anthocyanin biosynthesis genes

\begin{tabular}{|c|c|c|c|c|c|}
\hline \multirow[t]{2}{*}{ Categories } & \multirow[t]{2}{*}{ Proteins } & \multicolumn{2}{|l|}{ rice } & \multirow{2}{*}{$\begin{array}{l}\text { maize } \\
\text { Genes }\end{array}$} & \multirow{2}{*}{$\begin{array}{l}\text { petunia } \\
\text { Genes }\end{array}$} \\
\hline & & Genes & Locus & & \\
\hline \multirow[t]{16}{*}{$\begin{array}{l}\text { Structural } \\
\text { genes }\end{array}$} & Chalcone Synthesis & OsCHS1 & LOC_Os11g32650 & $C 2$ & $\begin{array}{l}\text { CHS1, } \\
\text { CHSB }\end{array}$ \\
\hline & $(\mathrm{CHS})$ & OsCHS2 & LOC_Os07g11440 & whp & $\begin{array}{l}\text { CHSG, } \\
\text { CHSJ }\end{array}$ \\
\hline & Chalcone Isomerase & \multirow[t]{2}{*}{$\mathrm{OsCHI/gh}$} & \multirow[t]{2}{*}{ LOC_Os03g60509 } & \multirow[t]{2}{*}{$\mathrm{ZmCHI1}$} & $C H I-A$ \\
\hline & $(\mathrm{CHI})$ & & & & $C H I-B$ \\
\hline & \multirow[t]{2}{*}{ Flavanone 3-hydrolase } & $\mathrm{OsF} 3 \mathrm{H}-1$ & LOC_Os04g56700 & \multirow[t]{4}{*}{$\mathrm{F} 3 \mathrm{H}$} & \multirow[t]{4}{*}{ An3 } \\
\hline & & OsF3H-2 & LOC_Os10g39140 & & \\
\hline & \multirow[t]{2}{*}{$(\mathrm{F} 3 \mathrm{H})$} & OsF3H-3 & LOC_Os04g57160 & & \\
\hline & & $\mathrm{OsF} 3 \mathrm{H}$ & LOC_Os03g03034 & & \\
\hline & Flavanone 3'-hydrolase & \multirow[t]{2}{*}{$O s F 3^{\prime} H$} & \multirow[t]{2}{*}{ LOC_Os10g17260 } & \multirow[t]{2}{*}{$\operatorname{Pr} 1$} & \multirow[t]{2}{*}{$H t 1 / H t 2$} \\
\hline & $\left(\mathrm{F}^{\prime} \mathrm{H}\right)$ & & & & \\
\hline & $\begin{array}{l}\text { Dihydroflavonol } \\
\text { Reductase }\end{array}$ & \multirow[t]{2}{*}{ OsDfr/Rd } & \multirow[t]{2}{*}{ LOC_Os01g44260 } & \multirow[t]{2}{*}{$A 1$} & \multirow[t]{2}{*}{ An6 } \\
\hline & (DFR) & & & & \\
\hline & Leucoanthocyanidin & OsANS1 & LOC_Os01g27490 & \multirow[t]{2}{*}{$A 2$} & \multirow[t]{2}{*}{-} \\
\hline & Dioxygenase (LDOX) & OsANS2 & LOC_Os06g42130 & & \\
\hline & $\begin{array}{l}\text { UDP-glycosyl } \\
\text { Transferase }\end{array}$ & \multirow[t]{2}{*}{ OsUGT } & \multirow[t]{2}{*}{ LOC_Os06g09240 } & \multirow[t]{2}{*}{$B z 1$} & \multirow[t]{2}{*}{-} \\
\hline & (UGT) & & & & \\
\hline \multirow{7}{*}{$\begin{array}{l}\text { Regulatory } \\
\text { genes }\end{array}$} & R2R3-MYB & OsC1 & LOC_Os06g 10350 & C1 & $A n 2$ \\
\hline & transcription factor & OsP1 & LOC_Os03g19120 & \multirow[t]{2}{*}{$P l$} & \\
\hline & & Kala3 & - & & \\
\hline & basic helix-loop-helix & OsB1/Ra1 & LOC_Os04g47080 & $R 1$ & An1 \\
\hline & transcription factor & OsB2/ Kala4 & LOC_Os04g47059 & $B 1$ & JAF13 \\
\hline & $(\mathrm{bHLH})$ & $R c$ & LOC_Os07g11020 & $L c$ & \\
\hline & & $R b$ & LOC_Os01g39560 & Sn & \\
\hline
\end{tabular}




\begin{tabular}{|llllll|}
\hline Categories & Proteins & rice & & maize & petunia \\
\cline { 3 - 5 } & & Genes & Locus & Genes & Genes \\
\hline & WD 40 repeat & OsPAC1 & LOC_Os02g45810 & PAC1 & An11 \\
\hline
\end{tabular}

\section{Structural genes}

The main enzymes that participate in the biosynthesis of anthocyanins are $\mathrm{CHS}, \mathrm{CH}, \mathrm{F} 3 \mathrm{H}, \mathrm{F}^{\prime} \mathrm{H}, \mathrm{F}^{\prime} \mathrm{S}^{\prime} \mathrm{H}$ and DFR (Fig. 1). As shown in Table 1, many structural genes encoding biosynthetic enzymes have been cloned and characterized in plants.

CHS is a key enzyme which catalyzes the initial step of anthocyanins biosynthesis. There are 12 different CHS genes in petunia, of which only four (CHSA, CHSB, CHSG, CHSJ) are expressed (Koes et al. 1989). whp and $c 2$, two $\mathrm{CHS}$ genes in maize, control the CHS activity in pollen and seeds, respectively (Franken et al. 1991; Wienand et al. 1986). The rice Os-CHS1 cDNA clone, firstly isolated from a leaf cDNA library of an indica variety, has extensive sequence homology with maize CHS genes (Reddy et al. 1996).

$\mathrm{CH}$ functions in the second step of anthocyanins biosynthesis, accelerating the isomerization of $p$ coumaroyl-CoA to produce naringenin. chi-A and $c h i-B$, two $C H /$ genes isolated from $P$. hybrida, are expressed in all floral organs and immature anthers respectively (van-Tunen et al. 1988). The petunia $P O$ gene, corresponding to chi-A, controls the $\mathrm{CHI}$ expression in anthers (van Tunen et al. 1991). The maize $Z m C H I 1$, isolated by gene homology, possesses $55 \%$ and $58 \%$ identity to $C h i-A$ and $C h i-B$ in petunia respectively (Grotewold and Peterson 1994). The rice $\mathrm{OsCH}$ gene is homologous with $\mathrm{ZmCHI1}$ (Drukaa et al. 2003), and mutation of $\mathrm{OsCHI}$ could lead to a golden hull and internode phenotype (Hong et al. 2012).

$\mathrm{F} 3 \mathrm{H}$ plays a pivotal role in producing the colorless precursors of anthocyanins. An3 is a functional gene of $\mathrm{F} 3 \mathrm{H}$ in petunia (Britsch and Grisebeach 1986), and $\mathrm{F} 3 \mathrm{H}$ is the only isolated gene of $\mathrm{F} 3 \mathrm{H}$ in maize (Deboo et al. 1995). There are three $F 3 H$ homologous genes in rice, namely OsF3H-1, OsF3H-2 and OsF3H-3, among which $\mathrm{OsF} 3 \mathrm{H}-2$ exhibits the highest expression level and $\mathrm{OsF} 3 \mathrm{H}-1$ possesses the highest enzyme activity (Jeong et al. 2007). LOC_OsO3g03034 is another gene encoding $\mathrm{F} 3 \mathrm{H}$, playing a role in $\mathrm{BPH}$ resistance (Dai et al. 2019).

DFR catalyzes the conversion of dihydroflavonols into respective leucoanthocyanidins. Among three $D F R$ genes identified in petunia, only $d f r A / A n 6$ is transcribed in floral tissues (Huits et al. 1994). The $A 1$ gene is a functional $D F R$ gene in maize and a recessive mutation at this locus leads to a colorless aleurone layer (Chen and Bennetzen 1996; Chen et al. 1998; Reddy et al. 1987). The rice DFR gene, OsDFR/Rd, is identical to the $A 1$ gene (Furukawa et al. 2007).

Several genes encoding F3'H, F3'5'H, ANS and 3-GT have been cloned in maize, which are $\operatorname{Pr} 1, A 2, B z 1$ and $B z 2$ respectively (Alfenito et al. 1998; Dooner and Nelson 1977; Menssen et al. 1990; Sharma et al. 2011). OsAns is identical to the maize ANS encoding gene $A 2$, and its mutant lines N2BB and G922 accumulate detectable amounts of proanthocyanidins and leucoanthocyanidins (Reddy et al. 1995). 
Through rice annotation project, several genes encoding $\mathrm{F}^{\prime} \mathrm{H}, \mathrm{ANS}$ and UGT have been annotated in rice (Table 1) (Tanaka et al. 2008).

\section{Regulatory genes}

There are mainly three types of genes which regulate the anthocyanin biosynthesis in plants, namely MYB TFs, basic helix-loop-helix (bHLH) TFs and WD40 TFs. Major genes involved in regulation of anthocyanins biosynthesis are listed in Table 1.

MYB TFs are of great importance in transcriptional control of multiple processes in higher plants (Martin and Paz-ares 1997). The R2R3 MYB TFs play a pivotal role in plants pigmentation(Allan et al. 2008). C1, the first cloned MYB type regulatory gene in maize, regulates the biosynthesis of anthocyanins in aleurone through regulating the transcription of $B z 1$ and $A 1$ (Bradley et al. 1991; Karen et al. 1986; PazAres et al. 1987). $P l$, another copy of $C 1$, mainly functions in the pigmentation in vegetative and floral organs in maize (Karen et al. 1993). An2, a main determinant of color differences in petunia, also encodes a MYB TF (Quattrocchio et al. 1999). As shown in Fig. 2, there are many MYB TFs in rice genome (Feller et al. 2011). However, only 3 genes were reported to be involved in anthocyanin biosynthesis. The MYB TF OsC1 can bind to the promoter elements of OsDFR and OsAns, and participates in flavonoid pathway and stress response through regulating the expression of OsDFR and OsAns (Ithal and Reddy 2004). The kala3 was reported to be a MYB TF but the function of it has not been characterized yet (Maeda et al 2014). A purple leaf mutant revealed that mutation in OSPL, a MYB TF, will affect anthocyanin biosynthesis and stress response (Akhter et al. 2019).

bHLH TFs are widely distributed in plants and participate in many biological processes including signal transduction and hormone response (Carretero-Paulet et al. 2010; Ogo et al. 2007; Zhang et al. 2009). They also function as determinants in anthocyanins biosynthesis. The maize $R$ and $B$ genes which are two bHLH domain containing genes act on the same anthocyanin biosynthetic pathway (Chandler and $\mathrm{V}$. 1989; Stephen et al. 1990). $L c$ and $S n$ are another two bHLH TFs in maize and the maize $L c$ and $C 1$ can complement the petunia an 2 and an 11 mutant phenotype respectively, which means that the regulatory genes controlling anthocyanin pigmentation are functionally conserved in plants (Francesca et al. 1993; Giuseppe et al. 1990; Steven et al. 1989). jaf13 and an 1 were two bHLHs in petunia and ecotypic expression of an2 and jaf13 could enhance the pigmentation in petunia (Cornelis et al. 2000; Francesca et al. 1998). As shown in Fig. 2, there are a total of $167 \mathrm{bHLHs}$ in rice genome that were distributed on 12 chromosomes (Carretero-Paulet et al. 2010; Li et al. 2006b). $R a$ and $R b$, two $R$ genes isolated from rice, are located on chromosome 4 and 1 respectively. The $R a$ locus consists of two genes, $R a 1$ and $R a 2$. Ra could activate the anthocyanin pathway in maize (Michael and Susan 1994), while $R b$ could induce the pigmentation in maize suspension cells (Hu et al. 2000). The Pllocus in rice, consisting of OsB1 and $O s B 2$, has been proved to be identical to $R a$ and $O s B 1$ is allelic to $R a 1$. Both $O s B 1$ and $O s B 2$ can induce the anthocyanin pathway in transient complementary experiments (Wataru et al. 2001). Rc, another bHLH gene located on chromosome 7 , is a determinant of proanthocyanin biosynthesis in rice pericarp (Sweeney et al., 2006). 
The pale aleurone color1 ( $p a c 1$ ) locus, encoding a WD40 repeat protein, is required for the anthocyanin biosynthesis in aleurone and scutellum in maize (Carey et al. 2004). However, the function of OsPAC1 is not clear (Zheng et al. 2019). A hypothesis was proposed that the MYB, bHLH and WD40 regulators can form a transcription complex and bind to the promoter of structural genes to activate the anthocyanins biosynthesis pathway (Koes et al. 2005; Ramsay and Glover 2005).

In rice, anthocyanin biosynthesis pathway is described as a CAP regulation system, with $C, A$ and $P$ standing for chromogen, activator and tissue-specific regulator respectively (Nagao and Takahashi 1963). In this system, both $A$ and $P$ are regulatory genes, while $C$ represents structural genes. The expression level of structural genes and regulatory genes are closely linked to the anthocyanin content. The expression level of OsCHS, OsF3H, OsDFR and OsAns in leaves and seeds of anthocyanin enriched varieties is higher than that of anthocyanin no-detectable varieties, and the expression of these genes is enhanced during seed maturation. Among that, OsDFR and OsAns have relatively high expression levels and are specific to anthocyanin biosynthesis (Kim et al. 2007). In non-pigmented rice lines, OsB2 is not expressed following illumination and a substitution in the $\mathrm{N}$-terminal interacting domain is observed in the OsB1 transcript (Shih et al. 2008). Whole genome sequencing along with transcriptomic sequencing in black rice plants identified several genes involving in anthocyanin biosynthesis, including $A N S 1, F 3 H$, UGT and DFR (Oh et al. 2018).

\section{Functional characterization of anthocyanin biosynthesis genes in different rice organs}

Most of anthocyanin related genes in rice were first isolated from cDNA hybridization to maize relative genes. With the rapid progress in genotype methods and functional genomics, a growing number of anthocyanin pigmentation genes have been positionally cloned and functionally analyzed in rice. The regulation mechanism of pigmentation in different rice tissues is increasingly clear (Fig. 3).

\section{Apiculus}

The occurrence of varying degrees of apiculus coloration is caused by diversity of the $C$ locus (Takahashi 1957). OsC1, a homologue of maize $C 1$ gene, is the functional gene underlying apiculus coloration variation. The colored apiculus $C 1$ allele in T65 contains three exons and encodes a 232-amino-acid protein containing a MYB domain at the $\mathrm{N}$ terminal, while the colorless apiculus allele in IR 36 and 868 is caused by a 10-bp deletion on the third exon, which leads to a frameshift and finally a loss-of-function of the protein (Saitoh et al. 2004).

\section{Pericarp}

Most cultivated rice varieties have colorless pericarp, but some varieties have brown, red or purple pericarp. The occurrence of red pericarp is due to the accumulation of proanthocyanins, of which the synthesis pathway is a branch of anthocyanin pathway and some identical biosynthetic genes are shared (Reddy et al. 1995; Tomoyuki et al. 2002; Winkel-Shirley 2001). Rc and $R d$ have been proposed to be the responsive genes of the red pericarp formation in rice. Functional alleles of $R c$ and $R d$ together produce 
red pericarp, functional allele of $R c$ alone produces brown pericarp, and functional allele of $R d$ alone produces white pericarp (Shao et al. 2011). A QTL rg7.1 on chromosome 7 was associated with red pericarp phenotype (Septiningsih et al. 2003), and fine mapping of rg7.1 revealed that LOC_Os07g11020 was the causal gene for $r g 7.1$, which encodes a bHLH TF. A 14-bp deletion was identified in white pericarp cultivars, which induced a frameshift and resulted in a premature stop and a truncated protein lacking the bHLH domain. Thus, LOC_OSO7g11020 is the Rc gene. Rc is expressed in both red and white pericarp varieties, but in white grained varieties, the $R c$ transcript is shortened due to the 14-bp deletion (Sweeney et al. 2006). Besides, a single C-A mutation on the sixth exon also leads to a premature stop codon before the bHLH domain and turns red pericarp into white pericarp. The 14-bp deletion is existed in $97.9 \%$ of white pericarp varieties, while the C-A mutation is present in less than $3 \%$ of white pericarp varieties, indicating that the C-A mutation is a rare mutation (Sweeney et al. 2007). Except for Rc, $q P C 10$ which encodes an $\mathrm{F} 3 \mathrm{H}$ was another gene responsible for the pericarp color in aus (Wang et al. 2016).

The black rice has been proved to be beneficial to human health and has drawn both consumers' and breeders' attention(Hou et al. 2010; Mbanjo et al. 2020). Previous researches have demonstrated that cyanidin 3-0-glucoside and peonidin 3-0-glucoside are the two primary anthocyanins in black rice pericarp (Abdel-Aal et al. 2006; Hu et al. 2003; Jand and Xu 2009). PURPLE PERICARP A (Pp, Prpa and Prp1) and PURPLE PERICARP B (Pb, Prpb and Prp2), two genes located on chromosome 1 and chromosome 4 respectively, are reported to be required for pigmentation of purple pericarp in rice (Hu et al. 1996; Mathilde et al. 1994; Shao et al. 2011; Wang and Shu 2007; Wang et al. 2009b). The Pb loci was previously fine mapped to a 25-kb region containing two annotated genes, $R a$ and $b h / h 16$. A 2-bp (GT) deletion in the seventh exon of $R a$ is existed in all the purple grained lines, indicating that $R a$ may be the $P b$ gene and the GT deletion may lead to the formation of purple pericarp (Wang and Shu 2007). Rahman revealed that the $P b$ allele was essential for the color development in purple rice pericarp and the $P p$ allele was incomplete dominant to the recessive $p p$ allele (Rahman et al. 2013). In addition, another research revealed that three regions on chromosome 1, 3 and 4 were associated with the black pigmentation in rice pericarp, which were named as Kala1, Kala3 and Kala4 respectively. The Kala1 locus was presumed to be $R d$ on chromosome 1, and Kala4 was in the same region of $P / / P b$. Yet, the Kala3 locus has not been identified before and was considered to encode a MYB TF. With the presence of functional Kala 1, Kala3 and Kala4, the rice pericarp is purple. Without functional Kala4, the rice pericarp is white (Maeda et al. 2014). Further fine mapping of Kala 4 revealed that the 0 s04g0557500 was responsible for the purple pericarp formation. Overexpression of 0 s04g0557500 will significantly promote the anthocyanin content in rice pericarp. The duplication in 0 s04g0557500 coding sequence along with a large fragment insertion into the promoter of 0 s04g0557500 was responsible for the black pericarp phenotype. Taken together, the black rice phenotype is caused by a gain-of-function mutation in Os04g0557500, which leads to a higher expression of Os04g0557500 (Oikawa et al. 2015). In a study of rice pericarp color using pair-wise comparison analysis for multiple pool-seq (PCAMP) identified several candidate genes, including $R d$, OsCHI, Kala4 and several genes encoding LDOX (Yang et al. 2019).

\section{Hull}


The rice hull color varies from purple, brown to white. A $C-S-A$ gene system was proposed for the regulation of rice hull color, in which $C 1$ encodes a R2R3 MYB transcription factor, $S 1$ encodes a bHLH protein and functions in a tissue-specific manner and $A 1$ encodes the DFR. C1 interacts with $\mathrm{S} 1$ and activates the expression of $A 1$. With the presence of functional $A 1$ allele, high level of cyanidin will be accumulated and the hull will turn purple, whereas loss-of-function of $A 1$ will lead to a brown hull color. An $\mathrm{F}_{4}$ population derived from a purple hull NIL and white hull variety, Nipponbare, was used to uncover the causal genes for the C-S-A system. The $O s C 1, K a l a 4$ and $R d$ are the causal genes for $C 1, S 1$ and $A 1$ respectively. Additionally, the $C 1$ along with $S 1$ can significantly upregulate the expression level of the structural genes in anthocyanin biosynthesis, but neither $C 1$ nor $S 1$ alone can influence the expression level of these genes. These results indicate that functional $C 1$ and $S 1$ are essential for the biosynthesis of anthocyanins and functional $A 1$ is the foundation of rice hull pigmentation (Sun et al. 2018).

\section{Leaf}

Anthocyanin accumulation in leaf sheath will produce purple leaf sheath in rice. Researchers found that the $0 s C 1$ allele co-segregated with the coloration of both the apiculus and the leaf sheath, suggesting that $\mathrm{OsC1}$ may be responsible for the variation of leaf sheath color (Fan et al. 2008). A mutant Z418 with purple leaf sheath which was regenerated from a green leaf sheath variety $\mathrm{C} 418$, has been proven to be caused by $0 s C 1$, of which a 34-bp longer transcript of OsC1 was observed in Z418 compared to that in C418, implying that the purple leaf sheath phenotype of Z418 is a functional obtained mutation of OsC1 (Gao et al. 2011). An $F_{2}$ population derived from TNG72 (with purple leaf sheath) and TCS17 (with green leaf sheath) was used to isolate the gene conferring leaf sheath color. Positional cloning revealed that a 10-bp and a 13-bp deletion in the R2R3 MYB domain of OsC1 was responsible for the formation of green leaf sheath in TCS17. Furthermore, it was concluded that the allelic diversity of OsC1, rather than the expression level, is the causal for the anthocyanin accumulation variation in rice leaf sheath (Chin et al. 2016).

Anthocyanins accumulation in rice leaves is reported to be controlled by $O s C 1, R b$ and $R d / D F R$ (Zheng et al. 2019).It is reported that OsC1 could influence cyanidin 3-O-glucoside content in rice leaves (Chen et al. 2014). Genomic sequence analysis of OsC1 demonstrated that five null mutations lead to the nonanthocyanin-pigmented leaves (non-AL) phenotype, whereas some varieties with functional OsC1 alleles still exhibit non-AL phenotype. A second GWAS analysis of anthocyanin in rice leaves using the varieties with functional $O s C 1$ alleles identified $R b$, a bHLH gene on chromosome 1. A 6.5-kb retrotransposon insertion into the 5'UTR of $R b$ decreases the expression level of $R b$ and leads to the non-AL phenotype. However, eight cultivars with functional $O s C 1$ and $R b$ alleles still show non-AL phenotype, due to a rare null mutation in the second exon of $D F R / R d$. Taken together, rice leaf coloration is controlled by a MYB gene $O s C 1$, a bHLH gene $R b$ and a chromatin gene $D F R / R d$.

\section{Evolutionary History Of Anthocyanins In Rice}


Rice has been domesticated for thousands of years and now is grown worldwide. Several genes like sh4 for shattering and prog 1 for erect growth have been selected during domestication, which significantly promote the harvest index of cultivated rice (Li et al. 2006a; Tan et al. 2008). Besides, grain appearance like grain color and grain size is also a domestication related trait (Choi et al. 2017; Izawa et al. 2009).

Grain color has been a target during domestication for the color of most cultivated rice is white while most wild rice color is red. The domestication of $R c$ and $R d$ counts for the selection of rice pericarp color (Konishi et al. 2008; Sweeney et al. 2006; Sweeney et al. 2007). Loss-of-function mutation of $R c$ produces white grains. About $97 \%$ of the white pericarp cultivars carry a 14-bp deletion which results in a premature stop codon and a nonfunctional $r c$ allele. The rest small percentage of white pericarp cultivars harbor a CA point mutation in exon 7 which is a null mutation and designated as $R c$-s. Haplotype analysis of $R c$ revealed that the 14-bp deletion arose from japonica and was introgressed into indica and aus, and the CA mutation originated in the aus subpopulation and was not widely disseminated during domestication (Sweeney et al. 2007). A unique null mutation in exon 7 of $R c$ inducing the formation of white pericarp in $O$. glaberrima was identified. Yet neither the 14-bp deletion or the $R c$-s mutation was observed in $O$. glaberrima. The mutation in white $O$. glaberrima Rc locus was in the same region of the Rc-s mutation, indicating that human selection may be identical in separate domesticated species (Gross et al. 2010). What is more, researchers suggested that the domestication process of white pericarp in aus is different from that in japonica and indica (Wang et al. 2016). Wang (2016) promoted that the Rc-s mutation turned the red pericarp to light red pericarp and the qPC10 mutation in the Rc-s background introduced the white pericarp. Both Rc-s and $q P C 10$ were selected in aus.

A model of japonica rice domestication was proposed based on three domestication related genes ( $W x$, $q S H 1$ and $q S W 5$ ), which indicated that japonica originated in Indonesia, the Philippines or a southern part of Indochina (Shomura et al. 2008). Two functional SNPs of $R d$, namely a G-T mutation in exon 1 named $r d 1$ and a C-A mutation in exon2 named $r d 2$, are existed in japonica. It was suggested that the $r d$ mutation occurred twice independently during japonica rice domestication. The $r d 2$ mutation was associated with the qsh1 mutation due to genetic linkage. The rd1 mutation may have originated in Philippines and been transferred into the ancestors of Japanese upland rice (Konishi et al. 2008). Researchers inferred that the possible reason for the selection of $r d$ may be the agronomic traits other than the pericarp color since the $r c$ mutation arose before the $r d$ mutation. It is noteworthy that the a 'Green revolution gene' $s d 1$ is also located in the $r d$ region of chromosome1 (Hironori et al. 2005). The combination of $r d q s h 1$ may be the result of the selection of $s d 1$ (Konishi et al. 2008).

Unlike the red pericarp, the black rice trait is a newly acquired trait, which is not observed in any wild rice accessions (http://www.gramene.org/). In ancient China, black rice was called as 'Emperor's rice' or 'forbidden rice' for its rarity (Newman 2004). Kala4/OsB2/Pb is reported to be essential for the purple pericarp formation in rice (Maeda et al. 2014; Rahman et al. 2013; Wang and Shu 2007). A large fragment insertion into the promoter of Kala 4 is a functional-gained mutation, which can significantly promote the expression level of Kala4. And the insertion was reported to be the original genetic change that gave birth to black rice (Oikawa et al. 2015). Furthermore, the nucleotide diversity of Kala4 in cultivated rice varieties 
revealed that the insertion first occurred in tropical japonica, and then spread to indica and subsequently temperate japonica through continuous natural crossing and artificial selection of black rice trait (Oikawa et al. 2015).

Most cultivated rice varieties do not accumulate anthocyanins. The anthocyanin accumulation in rice leaves are controlled by $O s C 1, R b$ and $R d$. Several mutations in $O s C 1$ are observed in cultivated rice, and indica and japonica carry loss-of-function mutations with independent origins. Thus, the OsC1 allelic diversification might have resulted from mutations in the coding region rather than from recombination between preexisting alleles (Saitoh et al. 2004). It was reported that OsC1 and $R b$ was selected independently (Zheng et al. 2019). The OsC1 mutation $c 1$ and $c 2$ were selected in indica and aus respectively, and the $r b$ mutation was selected in japonica. These negative selections of $O s C 1$ and $R b$ lead to the non-anthocyanin-accumulated leaf phenotype. And the reason for this negative selection may be that anthocyanin pigmentation in rice leaves influences the efficiency of photosynthesis, which will subsequently reduce rice yield (Zheng et al. 2019).

\section{Applications: Molecular Rice Breeding}

The anthocyanin content in rice is positively related to antioxidant activity and increasing the anthocyanin content in rice is beneficial for human health (Woo et al. 2011). These functionally characterized genes contribute to the molecular breeding of anthocyanin accumulated cultivars, as well as revealing the potential functions of anthocyanins in rice.

OsPR1.1 is a pathogen related gene that can be induced by pathogen attack or chemical treatment. The anthocyanin content can be increased when transgenic plants with OsB2 cDNA driven by OsPR1.1 promoter are treated with chemicals, indicating that it is possible to increase the anthocyanin accumulation through improving the expression level of OsB2 (Hiroyuki et al. 2007). However, although overexpression of $O s B 2$ significantly upregulated the expression level of several structural genes in anthocyanin biosynthesis, the anthocyanin accumulated phenotype was neither observed in the calli nor in positive transgenic plants of Taichung 65 (Chotipa et al. 2014). Introducing the maize $C 1$ and $R$-S gene driven by a rice endosperm specific promoter into a japonica variety resulted in highly concentrated anthocyanins in the cells of four to five outer endosperm layers, but chalky endosperm simultaneously. (Shin et al. 2006). $L c$ is a MYB transcription factor that regulates the anthocyanin accumulation in multiple organs in maize. Overexpression of $L c$ in rice significantly improved the anthocyanin content in floral organs, and spikelets, anthers and ovaries turned red. However, the intensive pigmented flowers were sterile and unable to mature naturally (Li et al. 2013). A significant increased expression of CHS gene was observed in the sterile plants, which means that upregulation of $\mathrm{CHS}$ gene expression would affect the normal development of rice seeds (Li et al. 2013). A novel transgenic rice was acquired by overexpression of OSANS in a rice mutant NP, which showed an increased accumulation of a mixture of flavonoids and anthocyanins and enhanced antioxidant potential (Reddy et al. 2007). 
Most of the functional mutations regulating anthocyanin biosynthesis have been elucidated and several functional markers have been developed (Table 2). $R c$ and $R d$ are involved in the red pericarp formation, and $O s B 1$, allelic to $R a 1$, is necessary for anthocyanin biosynthesis. Different alleles of these three genes are existed in the genomic sequences of black, red and white grained varieties. A C-A mutation in DFR/Rd is present in white grained cultivars. Both black pericarp and red pericarp rice carry a $C$ allele, and the white pericarp varieties all carry the A allele which leads to a premature stop codon. The Rcloci is nonfunctional in both black and white rice for a 14-bp deletion in the coding region that will truncate the functional domain of Rc protein. A GT insertion in OsB1 is present in both red rice and white rice varieties, which causes a frameshift and a premature stop codon. Based on these findings, two CAPs markers and an INDEL marker (Table 2) have been developed to assist in identification of rice seed color (Lim and Ha 2013). 
Table 2

Functional mutations and markers for anthocyanin biosynthesis genes

\begin{tabular}{|c|c|c|c|}
\hline Genes & Function & Alleles & Functional Mutations \\
\hline \multirow[t]{5}{*}{ OsC1 } & \multirow[t]{5}{*}{ R2R3-MYB } & $c 1$ & deletion at 795-804nt site \\
\hline & & $c 2$ & C-G mutation at $122 \mathrm{nt}$ \\
\hline & & $c 3$ & deletion at $785-786 \mathrm{nt}$ \\
\hline & & $c 4$ & deletion in $968-1012 \mathrm{nt}$ \\
\hline & & $c 5$ & deletion from 307-1294nt \\
\hline \multirow[t]{2}{*}{$R b$} & \multirow[t]{2}{*}{$\mathrm{bHLH}$} & Type2-Rb & $\begin{array}{l}6.5 \mathrm{~kb} \text { retrotransposon insertion in } \\
\text { the } 5^{\prime} \mathrm{UTR}\end{array}$ \\
\hline & & Type3- $R b$ & null amplification in 5'UTR \\
\hline OsB1/Ra & bHLH & $\begin{array}{l}\text { white pericarp- } \\
R a\end{array}$ & GT insertion in the seventh exon \\
\hline OsB2/Kala4 & bHLH & $\begin{array}{l}\text { purple pericarp } \\
\text { Kala4 }\end{array}$ & $11.0-\mathrm{kb}$ insertion in the promoter \\
\hline \multirow[t]{2}{*}{$R c$} & \multirow[t]{2}{*}{ bHLH } & rc & 14-bp deletion in the sixth exon \\
\hline & & $R c-s$ & C-A mutation in the sixth exon \\
\hline$R d / D F R$ & $\begin{array}{l}\text { Dihydroflavonol } \\
\text { Reductase }\end{array}$ & $r d$ & C-A non-sense mutation at exon 2 \\
\hline \multirow{6}{*}{$\begin{array}{l}\text { Functional } \\
\text { Markers }\end{array}$} & \multirow{2}{*}{$\begin{array}{l}\text { Identification for DFR } \\
\text { genotype }\end{array}$} & \multirow[t]{2}{*}{ CAPS-DFR } & 5'-CGCTTGCTTGACTCTGACAA-3' \\
\hline & & & 5'-GCTTGACCACCTCGTTCTCC-3' \\
\hline & \multirow{2}{*}{$\begin{array}{l}\text { Identification for } O s B 1 \\
\text { genotype }\end{array}$} & \multirow[t]{2}{*}{ CAPS-OsB1 } & 5'-CAGGCACCACACAGAGAATG - 3' \\
\hline & & & 5'-CATCCCAGGTTCGACGGCAG-3' \\
\hline & \multirow{2}{*}{$\begin{array}{l}\text { Identification for } R c \\
\text { genotype }\end{array}$} & \multirow[t]{2}{*}{ Indel-Rc } & 5'-CAGGCACCACACAGAGAATG-3' \\
\hline & & & 5'-GGTTGGCACTGAAATCACCT-3' \\
\hline
\end{tabular}

Black rice varieties have been favored by breeders and consumers for quite a long time and the cultivation traits have been improved by many researchers (Ito and Lacerda 2019). Maeda (2014) developed a black rice introgression line by backcrossing 'Hong Xie Nuo' with 'Koshihikari'. The eating quality of the black rice NIL, especially the overall value and glossiness, was superior to that of another black rice cultivar 'Okunomurasaki'. Even though black rice is beneficial for human health, anthocyanins are accumulated only in the pericarp and will be removed when rice grains are polished. Genetic engineering is a possible way to develop rice varieties with purple endosperm, such as the breeding of 'Golden rice' (Ye et al. 2000). Zhu developed a novel biofortified germplasm 'Purple endosperm Rice', which is called 'Zijingmi' in Chinese, through a high-efficiency vector system (Zhu et al. 2017). Eight 
anthocyanin-related genes driven by an endosperm-specific promoter are involved in this vector. The antioxidant activity either in the unpolished or polished grains of the purple endosperm rice lines is much higher than that of the transgenic negative lines.

Increasing the anthocyanin content in rice can enhance disease resistance. By transforming the maize anthocyanin regulatory genes $C 1, R$ and the structural gene $C 2$ into a japonica variety, Tp309, researchers observed an anthocyanin accumulation in the leaves and leaf sheath in the transgenic plants. In the meanwhile, the transgenic plants displayed a high resistance to the blast fungi (Gandikota et al. 2001).

\section{Further Research}

Through analyses of anthocyanins biosynthesis in different rice tissues, we can conclude that $R d$ is the fundamental gene of the anthocyanin pigmentation in rice and a MYB transcription factor along with a bHLH gene are necessary. $R b$ and Kala 4 are bHLH genes, which are essential for the leaf and pericarp pigmentation respectively. $R c$, another bHLH domain containing regulator, participates in the red pericarp formation. OsC1 and Kala3 are the only two reported MYB TFs and the function of Kala3 is not clear. LOC_Os03g19120, the closest homologue to ZmP1 which is a MYB transcription factor and regulates the anthocyanin biosynthesis in several organs (Erich et al. 1991), was designated as OsP1. It showed a higher expression correlation with early structural genes like $\mathrm{OsCHS}$ and $\mathrm{OsCHI}$ compared with $\mathrm{OsC1}$. However, OsP1 cannot directly interact with $O s B 1, O s B 2$ or $R b$ but $O s C 1$ can (Zheng et al. 2019). Thus, the role of $O s P 1$ in rice anthocyanin biosynthesis remains to be studied. OsB2 is necessary for the black rice formation, but its expression level is very low or even undetectable in rice leaves. What is more, OsB2 participates in the purple hull formation (Sun et al. 2018). Taken together, we can infer that OsB2 is essential for the anthocyanin biosynthesis in floral organs. $R c$ and $R b$ were reported only to be involved in the red pericarp formation and leaf pigmentation respectively, which mean that $R c$ and $R b$ may be tissue specific regulators in floral and vegetative organs respectively.

A locus conferring purple leaf sheath ( $P S H 1)$ was mapped to a $23.5 \mathrm{~kb}$ region on chromosome 1 . Six open reading frames were annotated but none of them is reported to be involved in anthocyanin biosynthesis (Wang et al. 2009a). OsC1 was reported to be responsible for the purple leaf sheath phenotype(Chin et al. 2016; Fan et al. 2008; Gao et al. 2011), which means that there are still other locus controlling the anthocyanins biosynthesis in leaf sheath. A rice ibf1 mutant with brown pigments accumulated in hull furrows was identified (Cui et al. 2007). The IBF1 gene was located on the long arm of chromosome 9, and OSKF1, annotated to encode a kelch repeat-containing F-box family protein, was reported to be the candidate gene for $I B F 1$, and was suggested to be a suppressor of brown pigmentation in rice hull furrows (Shao et al. 2012). Bh4, which encodes an amino acid transporter was reported to control the black hull phenotype in wild rice and a 22-bp deletion in the third exon disrupts the function of Bh4 and leads to the straw-white hull phenotype in cultivated rice (Zhu et al. 2011). Plr4, a recessive locus for purple leaf, was fine mapped to small region. Transcriptome sequencing further revealed that Os04g0577800 and Os04g0616400 might be the candidate genes for Plr4 (Gao et al. 2019). OsBBX14, a rice B-box protein was reported to participate in rice grain anthocyanin biosynthesis (Kim et al. 2018). 
Since OSKF1 and Bh4 are neither structural genes nor regulatory genes in rice anthocyanins biosynthetic pathway, there are still other genes that may regulate the anthocyanins in rice. OsC1 was reported to control the purple apiculus trait, yet the regulation of purple apiculus formation is still uncovered. Besides, little is known about the purple stigma phenotype.

The rice pericarp color has been reported to be associated with seed dormancy (Gu et al. 2005). Rice grains with red pericarp have a longer dormant period than those with white pericarp. qSD7/ qPC7, a QTL on chromosome 7, was reported to influence both the pericarp color and seed dormancy, and further fine mapping revealed that $R c$ was the functional gene for seed dormancy variation (Gu et al. 2011). Rice anthocyanin biosynthesis is responsive to stress, such as drought, high salt and ABA, and also involved in disease resistance (Gandikota et al. 2001; Ithal and Reddy 2004). Improving the anthocyanin content in rice pericarp may enhance the antioxidant activity and increase the seed dormancy in the meantime. And it is feasible to increase the resistance to biotic and abiotic stress through elevating the anthocyanin content in rice.

The evolution history of rice anthocyanin biosynthesis genes revealed that the purple leaf trait was negatively selected, and the black rice phenotype is a functional acquired mutation (Oikawa et al. 2015; Zheng et al. 2019). However, a decreased yield was observed in black rice compared to the white pericarp lines with similar background (Ji et al. 2012). Rice hull has long been treated as a waste product, but studies have demonstrated the antimutagenic and anticlastogenic potential of purple rice hull (Baek et al. 2015; Sankam et al. 2013). 'Green super rice' has become the goal of rice breeding since the beginning of this century and high yield with good quality is the main pursuit of rice breeders (Zhang 2007). With the improvement of living standards and health care consciousness, people are paying increasing attention to the healthy substances in food (Zhao et al. 2020; Zhou et al. 2019). Reducing the anthocyanin content in green tissues will enhance the photosynthesis efficiency and further increase rice yield. Increasing the anthocyanin content in rice grains will be beneficial for human health. With the increasingly elucidative pathway of anthocyanin biosynthesis and the rapid development of molecular breeding method, it is possible to breed novel rice varieties that are either rich or deficient in anthocyanins.

\section{Conclusion}

Anthocyanins in rice have diverse functions besides paint organs. The genetic basis of anthocyanins biosynthesis varies among different organs, but $R d$ is the identical gene in rice anthocyanins biosynthesis. OSC1, a MYB TF, is critical for anthocyanin biosynthesis in rice leaf, hull, apiculus and stigma. Kala3 is another MYB TF that regulates the anthocyanin biosynthesis in rice pericarp. OsRb, $O s B 2$ and $R c$ are bHLH TFs that influence the anthocyanin accumulation in rice leaf, rice pericarp and proanthocyanin accumulation in red rice respectively. Unlike $O s C 1, R c$ and $R d, O s B 2$ is a functional acquired mutation, which means that the black rice is a functional acquired phenotype. It is feasible to manipulate the anthocyanin content in rice organs through selecting functional alleles of related genes. Although tremendous progress has been made in the genetic basis of rice anthocyanin biosynthesis, there are still many unknows and challenges. Kala3 was reported to be a MYB transcription factor, but the 
function of it is still uncovered. The biosynthetic pathway of anthocyanin in rice awn, stigma, apiculus and leaf sheath remains undiscovered. Altogether, a comprehensive understanding of the molecular basis of anthocyanin biosynthesis in various rice organs is pivotal for rice improvement and breeding.

\section{Declarations}

\section{Acknowledgements}

Not applicable.

\section{Authors' Contribution}

DX and $\mathrm{YH}$ proposed the concept; $\mathrm{DX}, \mathrm{HZ}$ and $\mathrm{BW}$ drafted the manuscript; $\mathrm{YH}$ revised and finalized the manuscript. All the authors have participated sufficiently in the work to take public responsibility for all portions of the content. All authors read and approved the final manuscript.

\section{Funding}

This work was supported by grants from the National Program on R\&D of Transgenic Plants (2016ZX08009003-004) and earmarked fund for Agriculture Research System (CARS-01-03) in China.

\section{Availability of Data and Materials}

Not applicable.

\section{Ethics Approval and Consent to Participate}

Not applicable.

\section{Consent for Publication}

Not applicable.

\section{Competing Interests}

The authors declare that they have no competing interests.

\section{References}

Abdel-Aal ESM, Yougn JC, Rabalski I (2006) Anthocyanin Composition in Black, Blue, Pink, Purple, and Red Cereal Grains. J Agric Food Chem 54:4696-4704

Akhter D, Qin R, Nath UK, Eshag J, Jin X, Shi C (2019) A rice gene, OsPL, encoding a MYB family transcription factor confers anthocyanin synthesis, heat stress response and hormonal signaling. Gene 699:62-72 
Alfenito MR, Souer E, Goodman CD, Buell R, Mol J, Koes R, Walbot V (1998) Functional Complementation of Anthocyanin Sequestration in the Vacuole by Widely Divergent Glutathione S -Transferases. Plant Cell 10:1135-1149

Allan AC, Hellens RP, Laing WA (2008) MYB transcription factors that colour our fruit. Trends Plant Sci 13:99-102

Baek JA, Chung NJ, Choi KC, Hwang JM, Lee JC (2015) Hull extracts from pigmented rice exert antioxidant effects associated with total flavonoid contents and induce apoptosis in human cancer cells. Food Sci Biotechnol 24:241-247

Bradley AR, Stephen AG, Theodore MK, Michael EF (1991) C1- and R-Dependent Expression of the Maize Bz1 Gene Requires Sequences with Homology to Mammalian myb and myc Binding Sites. Plant Cell 3:317-325

Britsch L, Grisebeach H (1986) Purification and characterization of $₫ 2$ S)-flavanone 3-hydroxylase from Petunia hybrida. Eur J Biochem 156:569-577

Carey CC, Strahle JT, Selinger DA, Chandler VL (2004) Mutations in the pale aleurone color1 regulatory gene of the Zea mays anthocyanin pathway have distinct phenotypes relative to the functionally similar TRANSPARENT TESTA GLABRA1 gene in Arabidopsis thaliana. Plant Cell 16:450-464

Carretero-Paulet L, Galstyan A, Roig-Villanova I, Martínez-García JF, Bilbao-Castro JR, Robertson DL (2010) Genome-Wide Classification and Evolutionary Analysis of the bHLH Family of Transcription Factors in Arabidopsis, Poplar, Rice, Moss, and Algae. Plant Physiol 153:1398-1412

Chandler, V. L (1989) Two Regulatory Genes of the Maize Anthocyanin Pathway Are Homologous: Isolation of B Utilizing R Genomic Sequences. Plant Cell 1:1175-1183

Chen MS, Bennetzen JL (1996) Sequence composition and organization in the Sh2/A1-homologous region of rice. Plant Mol Biol 32:999-1001

Chen MS, SanMiguel P, Bennetzen JL (1998) Sequence Organization and Conservation in sh2/a1 Homologous Regions of Sorghum and Rice. Genetics 148:135-443

Chen W, Gao YQ, Xie WB, Gong L, Lu K, Wang WS, Li Y, Liu XQ, Zhang HY, Dong HX, Zhang W, Zhang LJ, Yu S, Wang GW, Lian XM, Luo J (2014) Genome-wide association analyses provide genetic and biochemical insights into natural variation in rice metabolism. Nat Genet 46:714-721

Chin HS, Wu YP, Hour AL, Hong CY, Lin YR (2016) Genetic and Evolutionary Analysis of Purple Leaf Sheath in Rice. Rice 9:8

Choi JY, Platts AE, Fuller DQ, Hsing YI, Wing RA, Purugganan MD (2017) The rice paradox: Multiple origins but single domestication in Asian rice. Mol Biol Evol 
Chotipa a, Srimek C, Poonsri I, Roypim S, Varaporn S (2014) Overexpression of OSB2 gene in transgenic rice up-regulated expression of structural genes in anthocyanin biosynthesis pathway. Thai $\mathrm{J}$ Genet 7:173-182

Ciulu M, Cadiz-Gurrea ML, Segura-Carretero A (2018) Extraction and Analysis of Phenolic Compounds in Rice: A Review. Molecules 23

Cornelis S, Francesca Q, Joseph NMM, Ronald K (2000) anthocyanin1 of Petunia Encodes a Basic HelixLoop-Helix Protein That Directly Activates Transcription of Structural Anthocyanin Genes. Plant Cell 12:1619-1632

Cui JJ, Fan SC, Shao T, Huang ZJ, Zheng DL, Tang D, Li M, Qian Q, Cheng ZK (2007) Characterization and Fine Mapping of the ibf Mutant in Rice. J Integr Plant Biol 49:678-685

Dai Z, Tan J, Zhou C, Yang X, Yang F, Zhang S, Sun S, Miao X, Shi Z (2019) The OsmiR396-OsGRF8OsF3H-flavonoid pathway mediates resistance to the brown planthopper in rice (Oryza sativa). Plant Biotechnol J 17:1657-1669

Deboo GB, Albertsen MC, Taylor LP (1995) Flavanone 3-hydroxylase transcripts and flavonol accumulation are temporally coordinate in maize anthers. Plant $\mathrm{J}$ 7:703-713

Dooner HK, Nelson OE (1977) Genetic Control of UDP glucose:Flavonol 3-O-Glucosyltransferase in the Endosperm of Maize. Biochem Genet 15:509-519

Dooner HK, Robbins TP, Jorgensen R (1991) Genetic and developmental control of anthocyanin biosynthesis. Annu Rev Genet 25:173-199

Drukaa A, Kudrnaa D, Rostoksa N, Brueggemana R, Wettsteina vD, Kleinhofs A (2003) Chalcone isomerase gene from rice (Oryza sativa ) and barley (Hordeum vulgare ): physical, genetic and mutation mapping. Gene 302:171-178

Erich G, Prasanna A, Thomas P (1991) Alternatively spliced products of the maize P gene encode proteins with homology to the DNA-binding domain of myb-like transcription factors. Proc Natl Acad Sci USA $88: 4587-4591$

Fan FJ, Fan YY, Du JH, Zhuang JY (2008) Fine Mapping of C (Chromogen for Anthocyanin) Gene in Rice. Rice Science 15:1-6

Feller A, Machemer K, Braun EL, Grotewold E (2011) Evolutionary and comparative analysis of MYB and bHLH plant transcription factors. Plant J 66:94-116

Francesca Q, John F.W., Hans TCL, Joseph NMM, Ronald EK (1993) Regulatory Genes Controlling Anthocyanin Pigmentation Are Functionally Conserved among Plant Species and Have Distinct Sets of Target Genes. Plant Cell 5:1497-1512 
Francesca Q, John FW, Karel VDW, Joseph NMM, Ronald K (1998) Analysis of bHLH and MYB domain proteins: speciesspecific regulatory differences are caused by divergent evolution of target anthocyanin genes. Plant J 13:475-488

Franken P, Niesbach-Klosgen U, Weydemann U, Marechal-Drouard L, Saedler H, Wienand U (1991) The duplicated chalcone synthase genes $\mathrm{C} 2$ and Whp (white pollen) of Zea mays are independently regulated; evidence for translational control of Whp expression by the anthocyanin intensifying gene in. The EMBO journal 10:2605-2612

Furukawa T, Maekawa M, Oki T, Suda I, lida S, Shimada H, Takamure I, Kadowaki K (2007) The Rc and Rd genes are involved in proanthocyanidin synthesis in rice pericarp. Plant $\mathrm{J}$ 49:91-102

Gandikota M, Kochko DA, Chen LL, Ithal N, Fauquet C, Reddy AR (2001) Development of transgenic rice plants expressing maize anthocyanin genes and increased blast resistance. Mol Breeding 7:73-83

Gao D, He B, Zhou Y, Sun L (2011) Genetic and molecular analysis of a purple sheath somaclonal mutant in japonica rice. Plant Cell Reports 30:901-911

Gao J, Dai G, Zhou W, Liang H, Huang J, Qing D, Chen W, Wu H, Yang X, Li D, Gao L, Deng G (2019) Mapping and Identifying a Candidate Gene PIr4, a Recessive Gene Regulating Purple Leaf in Rice, by Using Bulked Segregant and Transcriptome Analysis with Next-Generation Sequencing. Int J Mol Sci 20

Giuseppe G, Mariangela M, Gabriella C, Chiara T (1990) Sn, a Light-Dependent and Tissue-Specific Gene of Maize: the Genetic Basis of Its Instability. Genetics 125:193-199

Gross BL, Steffen FT, Olsen KM (2010) The molecular basis of white pericarps in African domesticated rice: novel mutations at the Rc gene. Journal of Evoluionary Biology 23:2747-2753

Grotewold E, Peterson T (1994) Isolation and characterization of a maize gene encoding chalcone flavonone isomerase. Mol Genet Genomics 242:1-8

Gu XY, Foley ME, Horvath DP, Anderson JV, Feng J, Zhang L, Mowry CR, Ye H, Suttle JC, Kadowaki K, Chen Z (2011) Association between seed dormancy and pericarp color is controlled by a pleiotropic gene that regulates abscisic acid and flavonoid synthesis in weedy red rice. Genetics 189:1515-1524

Gu XY, Kianian SF, Hareland GA, Hoffer BL, Foley ME (2005) Genetic analysis of adaptive syndromes interrelated with seed dormancy in weedy rice (Oryza sativa). Thero Appl Genet 110:1108-1118

Helen AS (1991) Flavonoid Evolution: An Enzymic Approach. Plant Physiol 96:680-685

Hironori N, Kazumitsu O, Mitsuhiro O, Yuki H, Yoshio S (2005) Genealogy of the "Green Revolution" gene in rice. Genes Genet Syst 80:351-356 
Hiroyuki K, Sakiko H, Takayoshi I, Yuko O, Wataru S, Masahiko M, Yasunobu O (2007) Chemically Induced Expression of Rice OSB2 under the Control of the OsPR1.1 Promoter Confers Increased Anthocyanin Accumulation in Transgenic Rice. J Agric Food Chem 55:1241-1247

Hong L, Qian Q, Tang D, Wang K, Li M, Cheng Z (2012) A mutation in the rice chalcone isomerase gene causes the golden hull and internode 1 phenotype. Planta 236:141-151

Hou Z, Qin P, Ren G (2010) Effect of anthocyanin-rich extract from black rice (Oryza sativa L. Japonica) on chronically alcohol-induced liver damage in rats. J Agric Food Chem 58:3191-3196

Hu C, Zawistowski J, Lling WH, Kitts DD (2003) Black Rice (Oryza sativa L. indica) Pigmented Fraction Suppresses both Reactive Oxygen Species and Nitric Oxide in Chemical and Biological Model Systems. J Agric Food Chem 51:5271-5277

Hu J, Reddy VS, Wessler SR (2000) The rice R gene family: two distinct subfamilies containing several miniature inverted-repeat transposable elements. Plant Molecular Biology 42:667-678

Hu JP, Anderson B, Wessler SR (1996) Isolation and Characterization Of Rice $R$ Genes Evidence for Distinct Evolutionary Paths in Rice and Maize. Genetics 142:1021-1031

Huits HSM, Gerats AGM, Kreike MM, Mol JNM, Koes RE (1994) Genetic control of dihydroflavonol 4reductase gene expression in Petunia hybrida. Plant J 6:295-310

Ithal N, Reddy AR (2004) Rice flavonoid pathway genes, OsDfr and OsAns, are induced by dehydration, high salt and $A B A$, and contain stress responsive promoter elements that interact with the transcription activator, OsC1-MYB. Plant Sci 166:1505-1513

Ito VC, Lacerda LG (2019) Black rice (Oryza sativa L.): A review of its historical aspects, chemical composition, nutritional and functional properties, and applications and processing technologies. Food Chem 301:125304

Izawa T, Konishi S, Shomura A, Yano M (2009) DNA changes tell us about rice domestication. Curr Opin Plant Biol 12:185-192

Jand SJ, Xu ZM (2009) Lipophilic and Hydrophilic Antioxidants and Their Antioxidant Activities in Purple Rice Bran. J Agric Food Chem 57:858-862

Jeong HK, Yoon JL, Bong GK, Yoongho L, Joong-Hoon A (2007) Flavanone 3 $\beta$-Hydroxylases from Rice: Key Enzymes for Favonol and Anthocyanin Biosynthesis. Mol Cell 25:312-316

Ji ZJ, Wang XG, Zeng YX, Ma LY, Li XM, Liu BX, Yang CD (2012) Comparison of physiological and yield traits between purple- and white-pericarp rice using SLs. Breed Sci 62:71-77

Joseph M, Erich G, Ronald K (1998) How genes paint flowers and seeds. Trends Plant Sci 30 
Karen CC, Frances AB, Benjamin B (1986) Molecular analysis of the maize anthocyanin regulatory locus Cl. Proc Natl Acad Sci USA 83:9631-9635

Karen CC, Suzy MC, Frances AB, Benjamin B (1993) Maize Anthocyanin Regulatory Gene $p /$ is a Duplicate of $c 1$ That Functions in the Plant. Plant Cell 5:1795-1805

Katiyar Amit, Smita S, Lenka SK, Rajwanshi R, Chinnusamy V, Bansal KC (2012) Genome-wide classification and expression analysis of MYB transcription factor families in rice and Arabidopsis. BMC Genomics 13:544

Kim BG, Kim JH, Min SY, Shin K, Kim JH, Kim HY, Ryu SN, Ahn J (2007) Anthocyanin content in rice is related to expression levels of anthocyanin biosynthetic genes. J Plant Biol 50:156-160

Kim DH, Park S, Lee JY, Ha SH, Lee JG, Lim SH (2018) A Rice B-Box Protein, OsBBX14, Finely Regulates Anthocyanin Biosynthesis in Rice. Int J Mol Sci 19

Koes R, Verweij W, Quattrocchio F (2005) Flavonoids: a colorful model for the regulation and evolution of biochemical pathways. Trends Plant Sci 10:236-242

Koes RE, Spelt CE, Mol JNM (1989) The chalcone synthase multigene family of Petunia hybrida (V30): differential, light-regulated expression during flower development and UV light induction. Plant Mol Biol $12: 213-225$

Konishi S, Ebana K, Izawa T (2008) Inference of the japonica Rice Domestication Process from the Distribution of Six Functional Nucleotide Polymorphisms of Domestication-Related Genes in Various Landraces and Modern Cultivars. Plant Cell Physiol 49:1283-1293

Li CB, Zhou AL, Sang T (2006a) Rice Domestication by Reducing Shattering. Science 311:1936-1939

Li X, Duan X, Jiang H, Sun Y, Tang Y, Yuan Z, Guo J, Liang W, Chen L, Yin J, Ma H, Wang J, Zhang D (2006b) Genome-wide analysis of basic/helix-loop-helix transcription factor family in rice and Arabidopsis. Plant Physiol 141:1167-1184

Li Y, Zhang T, Shen ZW, Xu Y, Li JY (2013) Overexpression of maize anthocyanin regulatory gene Lc affects rice fertility. Biotechnol Lett 35:115-119

Lim SH, Ha SH (2013) Marker development for the identification of rice seed color. Plant Biotechnol Rep 7:391-398

Maeda H, Yamaguchi T, Omoteno M, Takarada T, Fujita K, Murata K, lyama Y, Kojima Y, Morikawa M, Ozaki H, Mukaino N, Kidani Y, Ebitani T (2014) Genetic dissection of black grain rice by the development of a near isogenic line. Breed Sci 64:134-141

Martin C, Paz-ares J (1997) MYB transcription factors in plant. Trends Genet 
Mathilde AC, Theresa MF, Yong GC, Sang NA, Julapark C, WU KS, Xiao JH, Yu ZH, Pamela CR, Sandra EH, Gerard S, Susan RM, Steven DT (1994) Saturated Molecular Map of the Rice Genome Based on an Interspecific Backcross Population. Genetics 138:1251-1274

Mbanjo EGN, Kretzschmar T, Jones H, Ereful N, Blanchard C, Boyd LA, Sreenivasulu N (2020) The Genetic Basis and Nutritional Benefits of Pigmented Rice Grain. Front Genet 11:229

Menssen A, Hohmann S, Martin W, Schnable PS, Peterson PA, Saedler H, Gierl A (1990) The En/Spm transposable element of Zea mays contains splice sites at the termini generating a novel intron from a dSpm element in the A2 gene. The EMBO journal 9:3051-3057

Michael DP, Susan RW (1994) Molecular Evolution of the Plant R Regulatory Gene Family. Genetics 138: 849-854

Nagao S, Takahashi M (1963) Trial Construction of Twelve Linkage Groups in Japanese Rice:(Genetical Studies on Rice Plant, 怄). J Fac Agr Kyushu U 53:72-130

Ogo Y, Itai RN, Nakanishi H, Kobayashi T, Takahashi M, Mori S, Nishizawa NK (2007) The rice bHLH protein OsIRO2 is an essential regulator of the genes involved in Fe uptake under Fe-deficient conditions. Plant J 51:366-377

Oh JH, Lee YJ, Byeon EJ, Kang BC, Kyeoung DS, Kim CK (2018) Whole-genome resequencing and transcriptomic analysis of genes regulating anthocyanin biosynthesis in black rice plants. 3 Biotech 8:115

Oikawa T, Maeda H, Oguchi T, Yamaguchi T, Tanabe N, Ebana K, Yano M, Ebitani T, Izawa T (2015) The Birth of a Black Rice Gene and Its Local Spread by Introgression. Plant Cell 27:2401-2414

Paz-Ares J, Ghosal D, Wienand U, Petersont AP, Saedle H (1987) The regulatory cl locus of Zea mays encodes a protein with homology to myb proto-oncogene products and with structural similarities to transcriptional activators. The EMBO journal 6:3553-3558

Petroni K, Pilu R, Tonelli C (2014) Anthocyanins in corn: a wealth of genes for human health. Planta 240:901-911

Quattrocchio F, Wing J, Woude vdK, Souer E, Vetten dN, Mol J, Koes R (1999) Molecular Analysis of the anthocyanin2 Gene of Petunia and Its Role in the Evolution of Flower Color. Plant Cell 11:1433-1444

Rahman MM, Lee KE, Lee ES, Matin MN, Lee DS, Yun JS, Kim JB, Kang SG (2013) The genetic constitutions of complementary genes $\mathrm{Pp}$ and $\mathrm{Pb}$ determine the purple color variation in pericarps with cyanidin-3-0-glucoside depositions in black rice. J Plant Biol 56:24-31

Ramsay NA, Glover BJ (2005) MYB-bHLH-WD40 protein complex and the evolution of cellular diversity. Trends Plant Science 10:63-70 
Reddy AM, Reddy VS, Scheffler BE, Wienand U, Reddy AR (2007) Novel transgenic rice overexpressing anthocyanidin synthase accumulates a mixture of flavonoids leading to an increased antioxidant potential. Metab Eng 9:95-111

Reddy AR, Britsch L, Salamini F, Saedler H, and Rohde W (1987) The A1 (anthocyanin-1) locus in Zea mays encodes dihydroquercetin reductase. Plant Sci 52:7-13

Reddy AR, Scheffler B, Madhuri G, Srivastava MN, Kumar A, Sathyanarayanan PV, Nair S, Mohan M (1996) Chalcone synthase in rice (Oryza sativa L.): Detection of the CHS protein in seedlings and molecular mapping of the chs locus. Plant Mol Biol 32:735-743

Reddy VS, Dash S, Reddy AR (1995) Anthocyanin pathway in rice (Oryza sativa L.): identification of a mutant showing dominant inhibition of anthocyanins in leaf and accumulation of proanthocyanidins in pericarp. Thero Appl Genet 91:301-312

Ronald EK, Francesca Q, N.M.M J (1994) The Flavonoid Biosynthetic Pathway in Plants: Function and Evolution. BioEssays 16:123-132

Saitoh K, Onishi K, Mikami I, Thidar K, Sano Y (2004) Allelic Diversification at the C (OsC1) Locus of Wild and Cultivated Rice. Genetics 168:997-1007

Sankam P, Punvittayagul C, Sringam K, Chaiyasut C, Wongpoomchai R (2013) Antimutagenicity and anticlastogenicity of glutinous purple rice hull using in vitro and in vivo testing systems. Mol Cel Toxicol 9:169-176

Septiningsih EM, Trijatmiko KR, Moeljopawiro S, McCouch SR (2003) Identification of quantitative trait loci for grain quality in an advanced backcross population derived from the Oryza sativa variety IR64 and the wild relative O. rufipogon. Thero Appl Genet 107:1433-1441

Shao T, Qian Q, Tang D, Chen J, Li M, Cheng Z, Luo Q (2012) A novel gene IBF1 is required for the inhibition of brown pigment deposition in rice hull furrows. Thero Appl Genet 125:381-390

Shao Y, Jin L, Zhang G, Lu Y, Shen Y, Bao J (2011) Association mapping of grain color, phenolic content, flavonoid content and antioxidant capacity in dehulled rice. Thero Appl Genet 122:1005-1016

Sharma M, Cortes-Cruz M, Ahern KR, McMullen M, Brutnell TP, Chopra S (2011) Identification of the pr1 gene product completes the anthocyanin biosynthesis pathway of maize. Genetics 188:69-79

Shih $\mathrm{CH}$, Chu H, Tang LK, Sakamoto W, Maekawa M, Chu IK, Wang M, Lo C (2008) Functional characterization of key structural genes in rice flavonoid biosynthesis. Planta 228:1043-1054

Shin YM, Park HJ, Yim SD, Baek NI, Lee CH, An G, Woo YM (2006) Transgenic rice lines expressing maize $\mathrm{C} 1$ and R-S regulatory genes produce various flavonoids in the endosperm. Plant Biotechnol J 4:303-315 
Shomura A, Izawa T, Ebana K, Ebitani T, Kanegae H, Konishi S, Yano M (2008) Deletion in a gene associated with grain size increased yields during rice domestication. Nat Genet 40:1023-1028

Stephen AG, Theodore MK, Bradley AR, Michael EF, Karen CC, Radicella JP, Vicki LC (1990)

Transactivation of anthocyanin biosynthetic genes following transfer of $B$ regulatory genes into maize tissues. The EMBO journal 9:2517-2522

Steven RL, Ledare FH, Stephen LD, Susan RW (1989) Lc, a member of the maize R gene family responsible for tissue-specific anthocyanin production, encodes a protein similar to transcriptional activators and contains the myc-homology region. Proc Natl Acad Sci USA 82:7092-7096

Sun X, Zhang Z, Chen C, Wu W, Ren N, Jiang C, Yu J, Zhao Y, Zheng X, Yang Q, Zhang H, Li J, Li Z (2018) The C-S-A gene system regulates hull pigmentation and reveals evolution of anthocyanin biosynthesis pathway in rice. J Exp Bot 69:1485-1498

Sweeney MT, Thomson JM, Pfeil BE, McCouch S (2006) Caught Red-Handed: Rc Encodes a Basic HelixLoop-Helix Protein Conditioning Red Pericarp in Rice. Plant Cell 18:283-294

Sweeney MT, Thomson MJ, Cho YG, Park YJ, Williamson SH, Bustamante CD, McCouch SR (2007) Global dissemination of a single mutation conferring white pericarp in rice. PLos Genet 3:e133

Takahashi ME (1957) Aanalysis on Apiculus Color Genes Essential to Anthocyanin Coloration Rice. J Fac Agr Kyushu U 50:266-362

Tan LB, Li XR, Liu FX, Sun XY, Li CG, Zhu ZF, Fu YC, Cai HW, Wang XK, Xie DX, Sun CQ (2008) Control of a key transition from prostrate to erect growth in rice domestication. Nat Genet 40:1360-1364

Tanaka T, Antonio BA, Kikuchi S, Matsumoto T, Nagamura Y, Numa H, Sakai H, Wu J, Itoh T, Sasaki T, Aono R, Fujii Y, Habara T, Harada E, Kanno M, Kawahara Y, Kawashima H, Kubooka H, Matsuya A, Nakaoka H, Saichi N, Sanbonmatsu R, Sato Y, Shinso Y, Suzuki M, Takeda J, Tanino M, Todokoro F, Yamaguchi K, Yamamoto N, Yamasaki C, Imanishi T, Okido T, Tada M, Ikeo K, Tateno Y, Gojobori T, Lin YC, Wei FJ, Hsing YI, Zhao Q, Han B, Kramer MR, McCombie RW, Lonsdale D, O'Donovan CC, Whitfield EJ, Apweiler R, Koyanagi KO, Khurana JP, Raghuvanshi S, Singh NK, Tyagi AK, Haberer G, Fujisawa M, Hosokawa S, Ito Y, Ikawa H, Shibata M, Yamamoto M, Bruskiewich RM, Hoen DR, Bureau TE, Namiki N, Ohyanagi H, Sakai Y, Nobushima S, Sakata K, Barrero RA, Sato Y, Souvorov A, Smith-White B, Tatusova T, An S, An G, S OO, Fuks G, Fuks G, Messing J, Christie KR, Lieberherr D, Kim H, Zuccolo A, Wing RA, Nobuta K, Green PJ, Lu C, Meyers BC, Chaparro C, Piegu B, Panaud O, Echeverria M (2008) The Rice Annotation Project Database (RAP-DB): 2008 update. Nucleic Acids Res 36:D1028-1033

Timothy AH, Edwina CC (1995) Genetics and Biochemistry of Anthocyanin Biosynthesis. Plant Cell 7:1071-1083 
Tomoyuki O, Mami M, Mio K, Yoichi N, Shu F, Ikuo S, Tetsuo S (2002) Polymeric Procyanidins as RadicalScavenging Components in Red-Hulled Rice. J Agric Food Chem 50:7524-7529

van-Tunen AJ, Koes RE, Spelt CE, van der Krol AR, Stuitje AR, Mol JNM (1988) Cloning of the two chalcone flavanone isomerase genes from Petunia hybrida: coordinate, light-regulated and differential expression of flavonoid genes. The EMBO journal 7:1257-1263

van Tunen AJ, Mur LA, Recourt K, Gerats AGM, Joseph NMM (1991) Regulation and Manipulation of Flavonoid Gene Expression in Anthers of Petunia: The Molecular Basis of the Po Mutation. Plant Cell 3:39-48

Wang CX, Shu QY (2007) Fine mapping and candidate gene analysis of purple pericarp gene $P b$ in rice(Oryza sativa L囚). Chin Sci Bull 52:3097-3104

Wang H, Xu X, Vieira FG, Xiao Y, Li Z, Wang J, Nielsen R, Chu C (2016) The Power of Inbreeding: NGSBased GWAS of Rice Reveals Convergent Evolution during Rice Domestication. Mol Plant 9:975-985

Wang WY, Scoles G, Ding HF, Li GX, Jiang MS, Li RF, Liu X, Zhang Y, Yao FY (2009a) Delimitation of the $\mathrm{PSH} 1(\mathrm{t})$ gene for rice purple leaf sheath to a $23.5 \mathrm{~kb}$ DNA fragment. Genome 52:268-274

Wang XG, Ji ZJ, Cai J, Ma LY, Li XM, Yang CD (2009b) Construction of Near Isogenic Lines for Pericarp Color and Evaluation on Their Near isogenicity in Rice. Rice Science 16:261-266

Wataru S, Taku O, Keisuke K, Chikara M, Akira S, Minoru M, Kazuhiko N, Masahiko MJP, Physiology C (2001) The Purple leaf (PI) Locus of Rice: the \nPlw Allele has a Complex Organization and \nIncludes Two Genes Encoding Basic Helix-Loop-Helix Proteins Involved in\nAnthocyanin \nBiosynthesis:9

Wienand U, Weydemann U, Niesbach-Klosgen U, Peterson PA, and Saedler H (1986) Molecular cloning of the $\mathrm{c} 2$ locus of Zea mays, the gene coding for chalcone synthase. Mol Genet Genomics 203:202-207

Winkel-Shirley B (2001) Flavonoid Biosynthesis. A Colorful Model for Genetics, Biochemistry, Cell Biology, and Biotechnology. Plant Physiol 126:485-493

Woo DS, Jun YK, Mi JP, Sang-lk H, Hang WK, Ji-Eun R, Sea KO, Jin HL, Ki CJ, and You CS (2011) Relationship of Radical Scavenging Activities and Anthocyanin Contents in the 12 Colored Rice Varieties in Korea. J Korean Soc Appl Bi 54:693-699

Yang X, Xia X, Zhang Z, Nong B, Zeng Y, Wu Y, Xiong F, Zhang Y, Liang H, Pan Y, Dai G, Deng G, Li D (2019) Identification of anthocyanin biosynthesis genes in rice pericarp using PCAMP. Plant Biotechnol $\mathrm{J}$ 17:1700-1702

Ye XD, Al-Babili S, Kloti A, Zhang J, Lucca P, Beyer P, Potrykus I (2000) Engineering the Provitamin A ( $\beta$ Carotene) Biosynthetic Pathway into (Carotenoid-Free) Rice Endosperm. Science 287:303-305 
Zhang LY, Bai MY, Wu JX, Zhu JY, Wang H, Zhang ZG, Wang Wf, Sun Y, Zhao J, Sun XH, Yang HJ, Xu YY, Kim SH, Fujioka S, Lin WH, Chong K, Lu TG, Wang ZY (2009) Antagonistic HLH/bHLH Transcription Factors Mediate Brassinosteroid Regulation of Cell Elongation and Plant Development in Rice and Arabidopsis. Plant Cell 21:3767-3780

Zhang Q (2007) Strategies for developing Green Super Rice. Proc Natl Acad Sci USA 104:16402-16409

Zhao MC, Lin YJ, Chen H (2020) Improving nutritional quality of rice for human health. Thero Appl Genet

Zheng J, Wu H, Zhu H, Huang C, Liu C, Chang Y, Kong Z, Zhou Z, Wang G, Lin Y, Chen H (2019) Determining factors, regulation system, and domestication of anthocyanin biosynthesis in rice leaves. New Phytol 223:705-721

Zhou H, Xia D, He Y (2019) Rice grain quality-traditional traits for high quality rice and health-plus substances. Mol Breeding 40

Zhu BF, Si L, Wang Z, Zhou Y, Zhu J, Shangguan YY, Lu D, Fan D, Li C, Lin H, Qian Q, Sang T, Zhou B, Minobe $Y$, Han B (2011) Genetic control of a transition from black to straw-white seed hull in rice domestication. Plant Physiol 155:1301-1311

Zhu Q, Yu S, Zeng D, Liu H, Wang H, Yang Z, Xie X, Shen R, Tan J, Li H, Zhao X, Zhang Q, Chen Y, Guo J, Chen L, Liu YG (2017) Development of "Purple Endosperm Rice" by Engineering Anthocyanin Biosynthesis in the Endosperm with a High-Efficiency Transgene Stacking System. Mol Plant 10:918-929

\section{Figures}




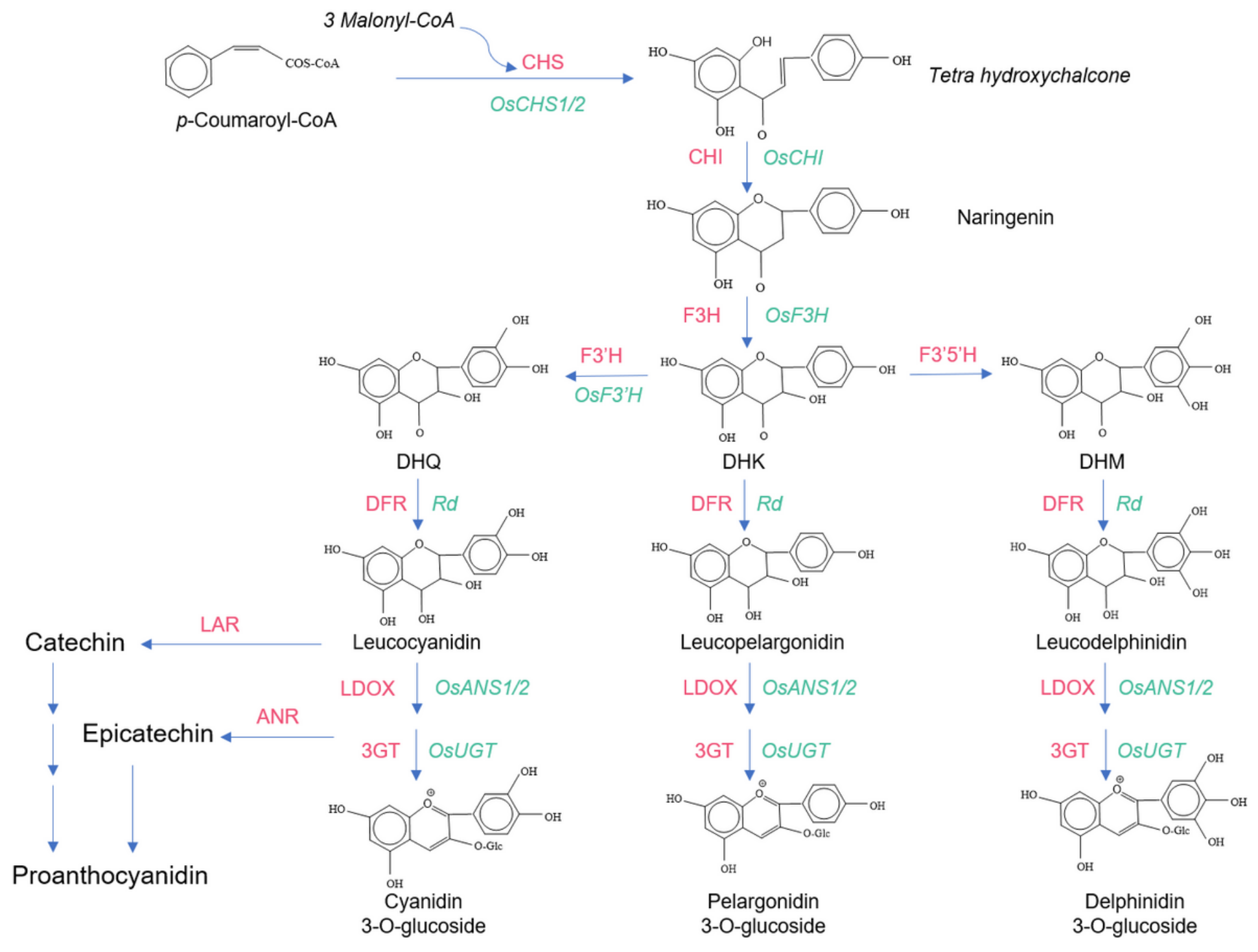

\section{Figure 1}

Simplified Diagram of Anthocyanins Biosynthetic Pathway. Words in red represent the synthesis enzyme and green represent the functional genes that encode the relative enzymes. $\mathrm{CHS}$, chalcone synthesis; $\mathrm{CHI}$, chalcone isomerase; $\mathrm{F3H}$, flavanone 3-hydroxylase; DHK, dihydrokaempferol; F3'H, flavonoid 3'hydroxylase; F3'5'H, flavonoid 3'5' hydroxylase; DHQ, dihydroquercetin; DHM, dihydromyricetin; DFR, dihydroflavonol 4-reductase; LDOX, leucoanthocyanidin oxidase; 3GT, 3-glucosyl transferase; LAR, leucoanthocyanidin reductase; ANR, anthocyanidin reductase. 


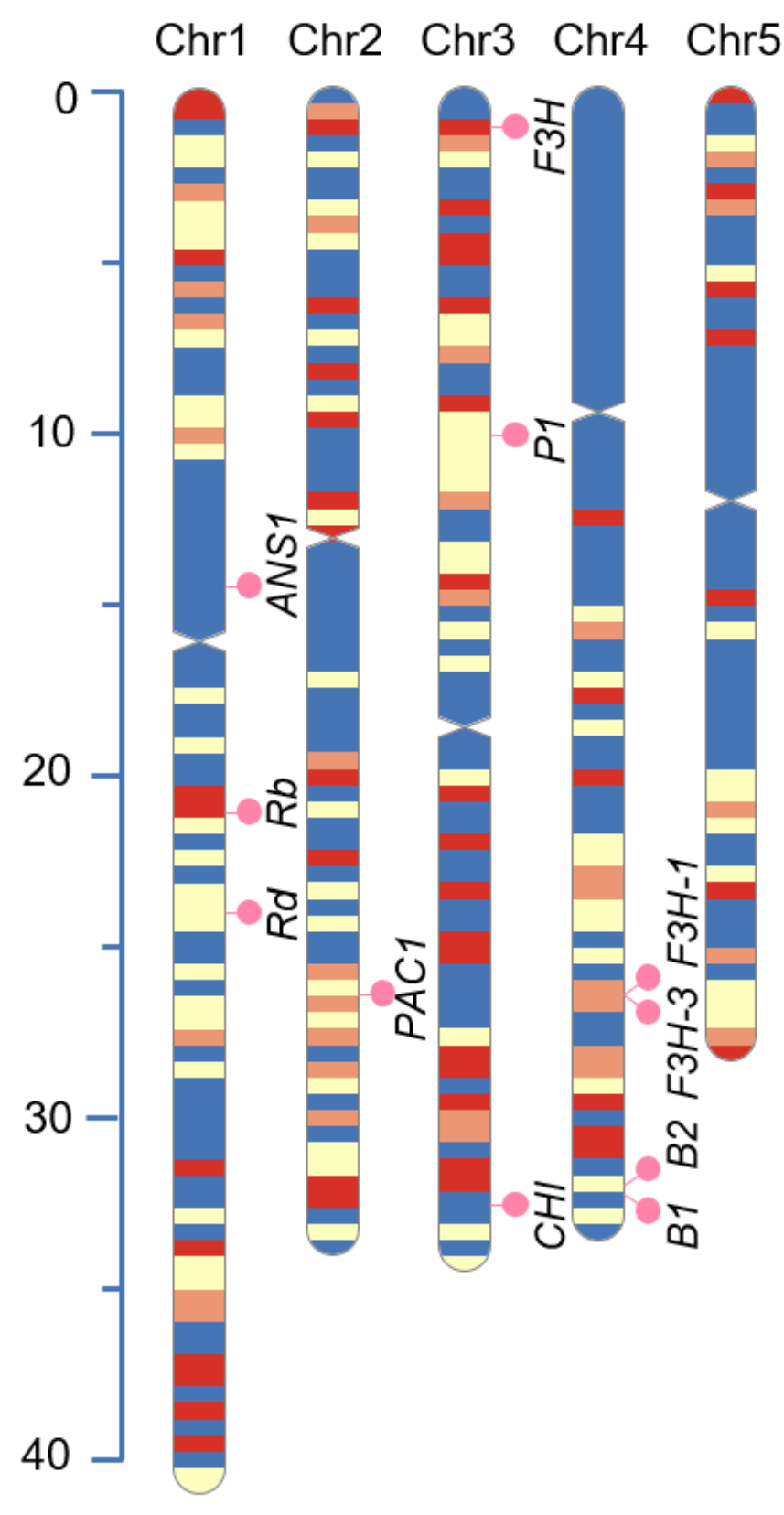

Chr6 Chr7 Chr8 Chr9 Chr10 Chr11 Chr12
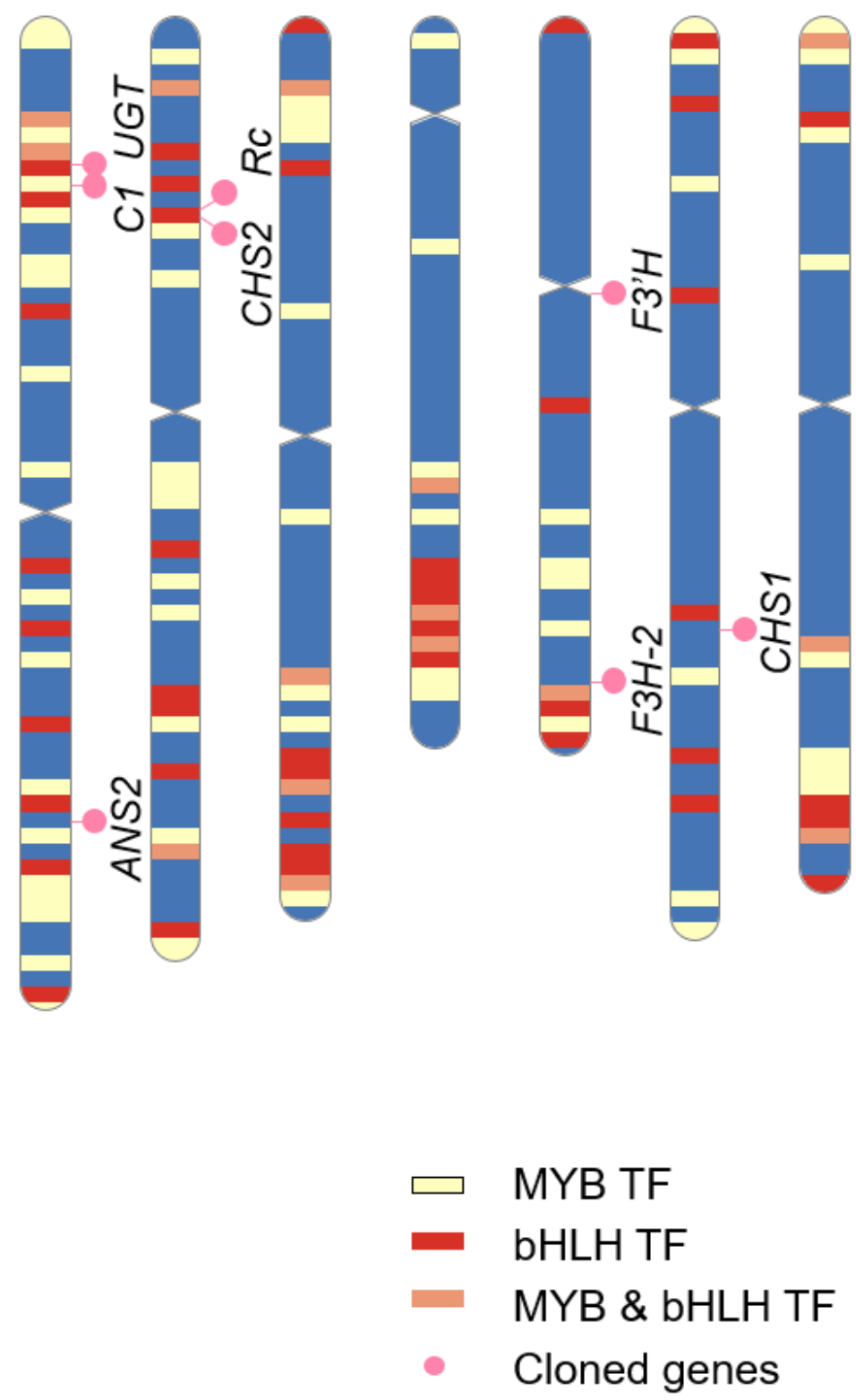

Figure 2

The distribution of Anthocyanin related genes on rice chromosomes. The yellow boxes represent the regions which contain MYB TFs in rice genome. The red boxes stand for the annotated bHLH TF in rice genome. The orange boxes stand for the regions that contains MYB TFs and bHLH TFs. The pink circle represents for the anthocyanin biosynthesis genes which have been cloned. 


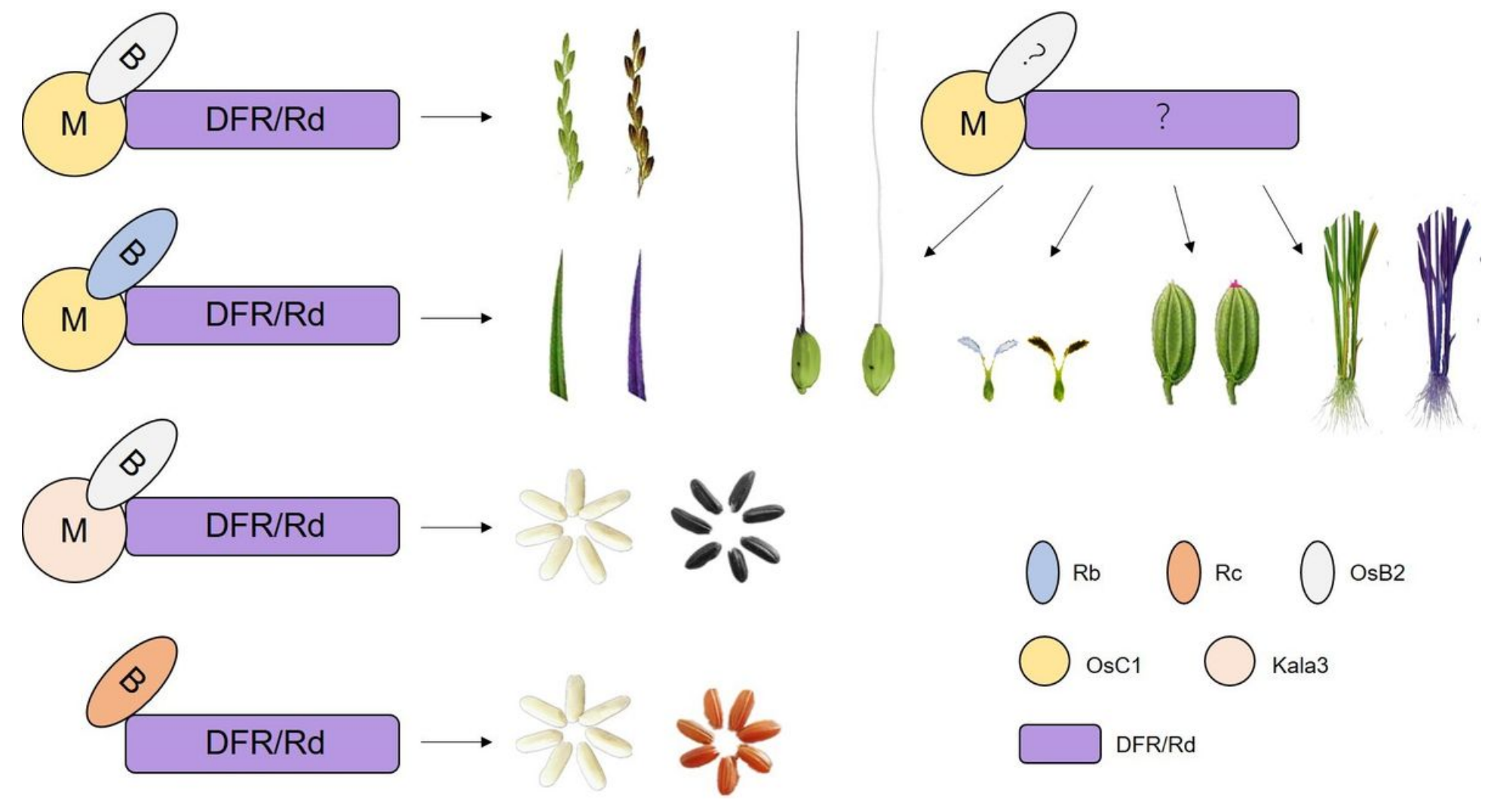

Figure 3

Anthocyanin biosynthesis regulation in various rice tissues. Round circle represents the MYB transcription factor. The yellow circle stands for the MYB transcription factor encoded by $\mathrm{OsC} 1$ and the pink circle for the MYB transcription factor encoded by Kala3. Ellipse represents the bHLH transcription factor. The light blue ellipse means the bHLH encoded by Rb, the orange ellipse means the bHLH encoded by Rc and the grey ellipse means the bHLH encoded by OsB2. The rectangle represents the functional anthocyanin biosynthetic protein. The purple rectangle means the functional enzyme encoded by DFR. The question marks in ellipse and rectangle represent uncharacterized bHLH and functional enzymes. 